\title{
TEMPORAL VARIATION IN VEGETATION INDEXES FOR PINE AND BEECH STANDS DURING THE VEGETATION SEASON, SZCZECIN LOWLAND, POLAND
}

\author{
PaWe€ PieKARSKI, ZBigniew ZwOLIŃSKi \\ Institute of Geoecology and Geoinformation, Adam Mickiewicz University in Poznań, Poland
}

Manuscript received: May 30, 2014

Revised version: August 5, 2014

\begin{abstract}
PIEKARSKI P., ZwOLIŃSKI Z., 2014. Temporal variation in vegetation indexes for pine and beech stands during the vegetation season, Szczecin Lowland, Poland. Quaestiones Geographicae 33(3), Bogucki Wydawnictwo Naukowe, Poznań, pp. 131-143, 2 tables, 7 figs. DOI 10.2478/quageo-2014-0037, ISSN 0137-477X.

AвSTRAст: Located in north-western Poland, the Bukowska Forest and Goleniowska Forest are vast woodlands consisting of areas with a homogeneous species composition that have been scarcely affected by humans. In this respect, they provided an excellent subject for scientific research, the purpose of which was to determine quantitative differences in selected vegetation indices of pine and beech stands in various periods during their vegetation seasons. Another purpose was to characterize the variation in these indices for each stand in its vegetation season. Four Landsat 5 TM images taken in 2007 and 2010 at four different points of vegetation season provided the basis for the analysis. In the analysis, 19 wooded areas with a homogeneous species composition were tested. In Bukowska Forest, the tested area was a beech stand, and in Goleniowska Forest, it was a pine stand. Acquired data was used to calculate the following vegetation indices: Normalized Difference Vegetation Index (NDVI), Transformed Vegetation Index (TVI), Green Normalized Difference Vegetation Index (Green NDVI), Normalized Difference Greenness Index (NDGI) and Normalized Difference Index (NDI). Subsequent research allowed to establish that the beech and pine stands differed significantly with respect to their calculated vegetation indices. These differences derived both from the biochemical and structural attributes of leaves and needles, as well as from transformations that occur in the stands during vegetation seasons. Analysis of the indices' allowed us to determine these differences and the influence of the stands' phenological phases on the indices.
\end{abstract}

KEY WORDS: spectral reflectance, pine forest, beech forest, vegetation indices, Landsat

Address of the corresponding author: Zbigniew Zwolinski, Institute of Geoecology and Geoinformation, Adam Mickiewicz University in Poznań, Dzięgielowa 27, 61-680 Poznań, Poland; e-mail: zbzw@amu.edu.pl

\section{Introduction}

Advances in satellite remote sensing technology allow for ever more precise measurements. Each subsequent sensor sent into orbit is superior to previous ones in terms of their spatial, radiometric and spectral resolution. Initially, the spatial resolution only allowed for determining variations in the size of woodland areas (Haapanen et al. 2004, Virk, King 2006), estimating their biomass (Zheng 2004) and locating deadwood areas (Zajączkowski, Wężyk 2000). Ikonos and QuickBird satellites offered data with a resolution of less than one meter. High-resolution images from these satellites provided the basis for numerous studies of woodland areas, including precise classifications of them (de Kok et al. 2005, Mallinis et al. 2008, Kim et al. 2009). Another milestone was the introduction of hyperspectral sensors. Their spectral resolution 
was further improved to a degree that permitted researchers to establish both the structural and biochemical attributes of trees. Hyperspectral data can reveal correlations between spectral reflectance and the amount of water contained in leaves (Colombo et al. 2008), their starch and lignin content ( $\mathrm{O}^{\prime} \mathrm{Neill}$ et al. 2002), and natural dyes such as chlorophyll (Daughtry et al. 2000; Gitelson et al. 2003; Wężyk et al. 2003; Castro, Sanchez-Azofeifa 2008), carotenoids (Wężyk et al. 2003) and anthocyanins (Sims, Gamon 2002). The data also allow to estimate nitrogen content and to determine woodland productivity (Smith et al. 2002). Advances in remote sensing technology have translated into research that is more precise, and allow researchers to obtain information in a faster and more comprehensive manner. Thus, remote sensing, whether based on satellite, aerial, or terrestrial measurements, facilitates environmental research and could possibly lead to the discovery of new theories or correlations (Zwoliński 2012).

This article presents the results of a comparative analysis of the vegetation indices of pine stands in Goleniowska Forest, and of beech stands in Bukowska Forest (in north-western Poland), conducted on the basis of satellite images from Landsat 5 TM. Beeches and pines were intentionally chosen for this analysis (Piekarski, Zwoliński 2012) because they play a significant role in the forestation of Poland (Przybylski 1970, Białobok 1990). The purpose of the paper is to establish differences in the vegetation indices in pine and beech stands, as well as to attempt to explain the character of variations in the vegetation indices of each stand during its vegetation season.

\section{Research area}

Bukowska Forest and Goleniowska Forest are located in north-western Poland, in the Szczecin Lowlands (Fig. 1). The Bukowska and Goleniowska Forests Promotional Forest Complex is dominated by pine and beech stands, with occasional oak stands, and, in areas featuring watercourses, alder and riparian stands, as well (Borówka 2004, Mirek at al. 2005, Rąkowski et al. 2005).

Environmental characteristics and forest surveys served as basis for selecting nineteen test ar- eas from satellite images (Fig. 2). All were woodland areas; nine were in Goleniowska Forest of areas ranging from 2.8 to $27.2 \mathrm{ha}, 116.5 \mathrm{ha}$ in total), nine - in Bukowska Forest (areas ranging from 3.6 to 22.1 ha, 95.2 ha in total). The major selection criterion was the homogeneity of the species composition of a stand. For Goleniowska Forest, these were pine stands, and for Bukowska Forest, beech stands. In both areas, the stands varied with regards to age (cf. Table 1). In Goleniowska Forest, the ages of the pines ranged from 39 to 74 years, with nine areas that were homogeneous with respect to age. The trees in the Bukowska Forest dated back between 30 to over 150 years, with seven homogeneous and two moderately heterogeneous areas.

\section{Data}

Images used for analysis came from a Thematic Mapper sensor located onboard the Landsat 5 satellite. Only images completely free of overcast were considered for use. Ultimately, four spectral images were selected, taken during the vegetation season on the following days: 29 April 2007, 10 July 2010, 12 September 2010, 30 October 2010, each falling in distinct thermal seasons according to the Lorenc system (2005): once each in spring and winter, and twice in summer. The images included seven spectral bands, six of which were used in the analysis: 1 - blue $(0.45-0.52 \mu \mathrm{m}), 2$ - green $(0.52-0.60 \mu \mathrm{m}), 3$ - red $(0.63-0.69 \mu \mathrm{m}), 4$ - near-infrared $(0.76-0.90 \mu \mathrm{m}), 5$ - short-wavelength infrared (1.55-1.75 $\mu \mathrm{m})$, and 7 - short-wavelength infrared (2.08-2.35 $\mu \mathrm{m})$. Channel no. 6 was excluded due to its low spatial resolution relative to other channels.

Survey data for the analysis were obtained from, respectively: the Kliniska Forest Inspectorate in the case of Goleniowska Forest, and the Gryfino Forest Inspectorate in the case of Bukowska Forest. Maps of forest sub-units were scanned and superimposed onto geographic coordinates based on reference points derived from cadastral data available from www.geoportal.gov.pl. The Universal Transverse Mercator coordinate system was used to georeference the selected satellite images. After being georeferenced, forest sub-units were vectorized, and test areas were 


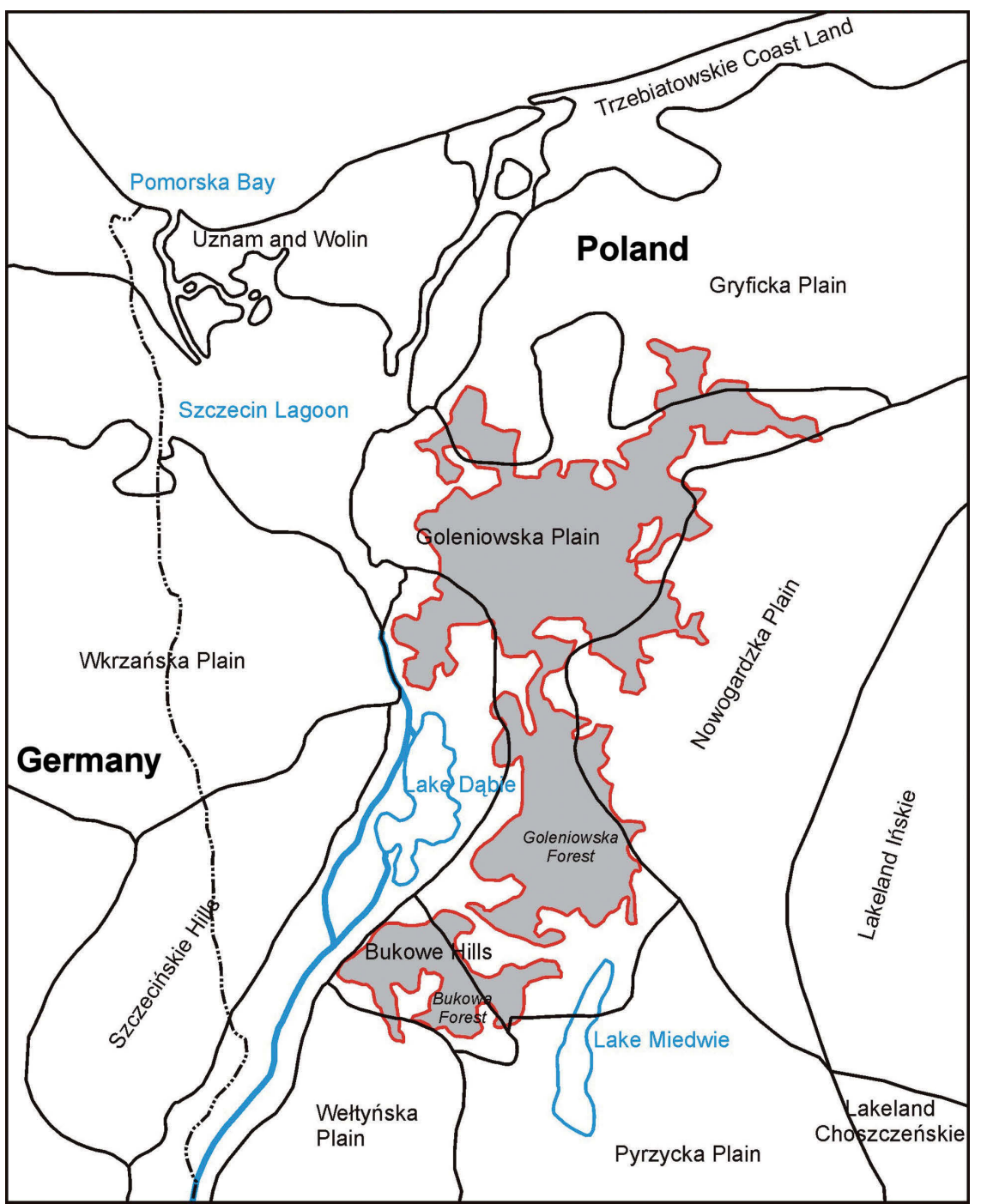

Fig. 1. The location of Goleniowska Forest and Bukowska Forest superimposed against a regional division of Poland (Kondracki 2009, altered)

divided into polygons based on the species composition of the stands.

\section{Research methods}

Before analysis, radiometric and topographic correction was conducted. Radiometric correction was performed using a script for TNTmips software created by Paris (2005), which converts digital numbers to the Standardized Reflectance Factor Index (SRFI). Using information contained in the metadata on the sun's angle of incidence and the date the image was taken, the script calculates the reflectance factor for the upper layers of the atmosphere. The script also reduces the influence of atmosphere on the spectral reflectance values.
Topographic correction was conducted using Paris' script (2005), which corrects standardized reflectance factor index for shaded areas. For this purpose, a digital elevation model, obtained from the NASA website (2008), prepared on the basis of Shuttle Radar Topography Mission was used. The procedure of correction allowed obtaining homogeneously lit satellite views.

Another stage of work was generating the spectral characteristics of the stands. Vector layers were superimposed onto each satellite image in the form of polygons demarcating the test areas. For each area, the average value for the reflectance index was calculated for each of the six analyzed spectral bands. The calculation was based on all the cells of the raster image, whose centres were located within the vector layer (cen- 


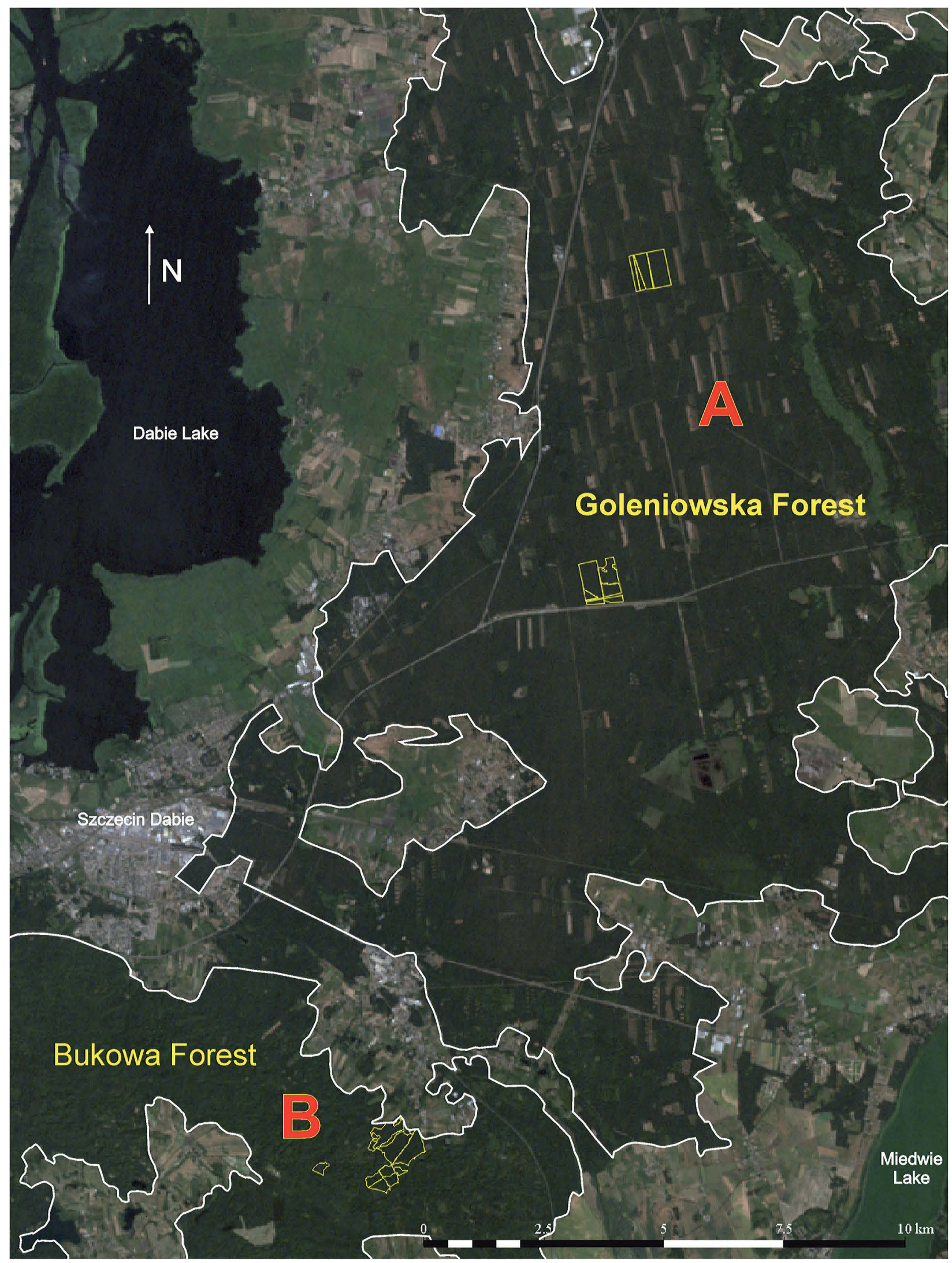

Fig. 2. Satellite image representing the Szczecin Lowland together with test area A (Goleniowska Forest with pine stands) and B (Bukowska Forest with beech stands) 
Table 1. Values for spectral reflectance [SRFI] of visible radiation (channels 1, 2 and 3) for beech and pine stands at various points of the vegetation season

\begin{tabular}{|c|c|c|c|c|c|c|c|c|c|c|c|c|c|}
\hline \multirow{3}{*}{$\begin{array}{l}\text { Test } \\
\text { area }\end{array}$} & \multirow{3}{*}{$\begin{array}{l}\text { Age of trees } \\
\text { (percentage of the } \\
\text { entire stand) }\end{array}$} & \multicolumn{12}{|c|}{ Spectral channels } \\
\hline & & 1 & 2 & 3 & 1 & 2 & 3 & 1 & 2 & 3 & 1 & 2 & 3 \\
\hline & & \multicolumn{3}{|c|}{29.04 .2007} & \multicolumn{3}{|c|}{10.07 .2010} & \multicolumn{3}{|c|}{12.09 .2010} & \multicolumn{3}{|c|}{30.10 .2010} \\
\hline \multicolumn{14}{|c|}{ Goleniowska Forest } \\
\hline pine1 & $\begin{array}{c}52 \text { years }-80 \% \\
69 \text { years }-20 \%\end{array}$ & 243 & 321 & 272 & 175 & 263 & 214 & 183 & 282 & 179 & 379 & 458 & 355 \\
\hline pine2 & 74 years $-100 \%$ & 255 & 324 & 271 & 191 & 266 & 219 & 206 & 285 & 195 & 375 & 472 & 355 \\
\hline pine3 & 74 years $-100 \%$ & 237 & 313 & 271 & 194 & 278 & 227 & 195 & 288 & 203 & 366 & 412 & 331 \\
\hline pine4 & 54 years $-100 \%$ & 240 & 319 & 271 & 186 & 274 & 232 & 182 & 282 & 190 & 394 & 456 & 361 \\
\hline pine5 & 74 years $-100 \%$ & 238 & 314 & 269 & 177 & 271 & 223 & 182 & 289 & 184 & 381 & 461 & 361 \\
\hline pine6 & 74 years $-100 \%$ & 242 & 309 & 268 & 171 & 273 & 228 & 185 & 293 & 200 & 385 & 418 & 348 \\
\hline pine7 & 69 years $-100 \%$ & 227 & 315 & 262 & 174 & 268 & 203 & 163 & 270 & 168 & 375 & 452 & 353 \\
\hline pine8 & 43 years $-100 \%$ & 228 & 307 & 249 & 177 & 258 & 192 & 162 & 266 & 164 & 415 & 445 & 337 \\
\hline pine9 & 39 years $-100 \%$ & 240 & 307 & 242 & 183 & 264 & 205 & 175 & 283 & 174 & 396 & 450 & 352 \\
\hline pine10 & 69 years $-100 \%$ & 229 & 315 & 251 & 172 & 268 & 200 & 164 & 271 & 165 & 371 & 437 & 342 \\
\hline Min & - & 227 & 307 & 242 & 171 & 258 & 192 & 162 & 266 & 164 & 366 & 412 & 331 \\
\hline Mean & - & 238 & 314 & 263 & 180 & 268 & 214 & 180 & 281 & 182 & 384 & 446 & 349 \\
\hline $\operatorname{Max}$ & - & 255 & 324 & 272 & 194 & 278 & 232 & 206 & 293 & 203 & 415 & 472 & 361 \\
\hline SD & - & 8.4 & 5.9 & 11.1 & 8.1 & 5.8 & 13.5 & 14.2 & 9 & 14.4 & 14.6 & 18.8 & 9.9 \\
\hline \multicolumn{14}{|c|}{ Bukowska Forest } \\
\hline beech1 & 67 years $-100 \%$ & 272 & 610 & 342 & 145 & 243 & 150 & 195 & 311 & 194 & 304 & 474 & 827 \\
\hline beech2 & 67 years $-100 \%$ & 267 & 606 & 322 & 142 & 235 & 154 & 186 & 304 & 187 & 300 & 451 & 765 \\
\hline beech3 & 62 years $-100 \%$ & 279 & 614 & 348 & 157 & 263 & 161 & 201 & 318 & 199 & 308 & 477 & 829 \\
\hline beech4 & $\begin{array}{c}40 \text { years }-60 \% \\
30 \text { years }-30 \% \\
60 \text { years }-10 \%\end{array}$ & 280 & 616 & 348 & 167 & 259 & 158 & 191 & 309 & 190 & 297 & 453 & 766 \\
\hline beech5 & 150 years $-100 \%$ & 261 & 622 & 335 & 147 & 254 & 149 & 180 & 321 & 202 & 298 & 440 & 737 \\
\hline beech6 & 152 years $-100 \%$ & 264 & 610 & 336 & 134 & 263 & 156 & 188 & 324 & 207 & 309 & 457 & 671 \\
\hline beech7 & 112 years $-100 \%$ & 262 & 588 & 325 & 131 & 269 & 155 & 195 & 332 & 200 & 266 & 383 & 624 \\
\hline beech8 & 132 years $-100 \%$ & 255 & 630 & 324 & 137 & 241 & 147 & 188 & 324 & 197 & 263 & 388 & 602 \\
\hline beech 9 & $\begin{array}{l}40 \text { years }-80 \% \\
55 \text { years }-20 \%\end{array}$ & 258 & 610 & 330 & 165 & 269 & 167 & 203 & 320 & 206 & 292 & 526 & 803 \\
\hline Min & - & 255 & 558 & 332 & 131 & 235 & 147 & 180 & 304 & 187 & 263 & 383 & 602 \\
\hline Mean & - & 266 & 612 & 334 & 147 & 255 & 155 & 192 & 318 & 198 & 293 & 450 & 763 \\
\hline Max & - & 280 & 630 & 348 & 167 & 269 & 167 & 203 & 332 & 207 & 309 & 526 & 829 \\
\hline SD & - & 8.8 & 11.6 & 10 & 13.2 & 12.6 & 6.3 & 7.4 & 8.7 & 6.7 & 17 & 44 & 85 \\
\hline
\end{tabular}

tral point algorithm). In this way, each test area was assigned average values for the standardized reflectance factor index for each of the six spectral channels and four periods in the vegetation season.

Then, the vegetation indices for each of the four periods in the vegetation season were calculated for each test area. The following five vegetation indices were selected for comparison: the Normalized Difference Vegetation Index - NDVI (Rouse et al. 1973), Transformed Vegetation Index - TVI (Rouse et al. 1973), Green Normalized Difference Vegetation Index - Green NDVI (Gitelson et al. 1996), Normalized Difference Green- ness Index - NDGI (Chamard et al. 1991 after Bannari et al. 1995) and the Normalized Difference Index - NDI (McNairn, Protz 1993 after Bannari et al. 1995).

\section{Results and interpretation}

Spectral reflectance was analysed for all the satellite images, and the results were compiled in two synthetic Sandarized Reflectance Factor Index (SFRI) tables, one for the visible spectrum (Table 1), and a second for the infrared spectrum (Table 2). These were used to calculate five veg- 
etation indices and to create graphs illustrating change over time in the indices for beech and pine stands in the months of the vegetation season studied.

\section{Visible spectrum}

Analysis of the SRFI table illustrating the visible spectrum (Table 1) reveals that the greatest differences in reflectance for the analyzed tree species occurred between 29.04.2007 and 30.10.2010. In April, the greatest difference occurred for the green radiation spectrum (channel 2 ). The average for the reflectance index for pine stands was 298 SFRI units lower than for beech, meaning it was less by almost half. This is explained by differences in the chlorophyll content in pine needles and beech leaves. Because beech trees grow new leaves at the turn of April and May, chlorophyll content in beech leaves during this period is at its lowest for the entire vegetation season (Vanseveren 1973 after Oleksyn 1990). This results in higher reflectance because chlorophyll concentration is inversely proportional to reflectance in the green channel (Daughtry et al. 2000).

Reflectance values in the green channel in pine stands are higher in spring than in summer due

Table 2. Values for spectral reflectance [SRFI] of infrared radiation (channels 4, 5 and 7) for beech and pine stands at various points of the vegetation season

\begin{tabular}{|c|c|c|c|c|c|c|c|c|c|c|c|c|c|}
\hline \multirow{3}{*}{$\begin{array}{l}\text { Test } \\
\text { area }\end{array}$} & \multirow{3}{*}{$\begin{array}{l}\text { Age of trees } \\
\text { (percentage of the } \\
\text { entire stand) }\end{array}$} & \multicolumn{12}{|c|}{ Spectral channels } \\
\hline & & 4 & 5 & 7 & 4 & 5 & 7 & 4 & 5 & 7 & 4 & 5 & 7 \\
\hline & & \multicolumn{3}{|c|}{29.04 .2007} & \multicolumn{3}{|c|}{10.07 .2010} & \multicolumn{3}{|c|}{12.09 .2010} & \multicolumn{3}{|c|}{30.10 .2010} \\
\hline \multicolumn{14}{|c|}{ Goleniowska Forest } \\
\hline pine1 & $\begin{array}{l}52 \text { years }-80 \% \\
69 \text { years }-20 \%\end{array}$ & 1692 & 1076 & 542 & 1885 & 844 & 375 & 2046 & 820 & 347 & 2838 & 1180 & 483 \\
\hline pine2 & 74 years $-100 \%$ & 1652 & 1096 & 557 & 1862 & 872 & 398 & 2016 & 854 & 360 & 2746 & 1206 & 462 \\
\hline pine3 & 74 years $-100 \%$ & 1634 & 1088 & 560 & 1834 & 891 & 416 & 1960 & 864 & 381 & 2610 & 1203 & 509 \\
\hline pine4 & 54 years $-100 \%$ & 1688 & 1053 & 538 & 1892 & 876 & 399 & 2054 & 846 & 358 & 2865 & 1199 & 473 \\
\hline pine5 & 74 years $-100 \%$ & 1673 & 1063 & 536 & 1856 & 866 & 388 & 1981 & 843 & 362 & 2718 & 1202 & 487 \\
\hline pine6 & 74 years $-100 \%$ & 1667 & 1078 & 556 & 1870 & 880 & 409 & 1995 & 876 & 378 & 2667 & 1220 & 518 \\
\hline pine7 & 69 years $-100 \%$ & 1777 & 1053 & 519 & 1978 & 848 & 363 & 2120 & 837 & 351 & 2872 & 1215 & 507 \\
\hline pine8 & 43 years $-100 \%$ & 1829 & 972 & 470 & 2012 & 783 & 333 & 2203 & 780 & 315 & 3023 & 1157 & 487 \\
\hline pine9 & 39 years $-100 \%$ & 1824 & 984 & 481 & 1968 & 834 & 386 & 2166 & 827 & 355 & 2983 & 1201 & 491 \\
\hline pine10 & 69 years $-100 \%$ & 1796 & 1030 & 497 & 1973 & 849 & 370 & 2087 & 819 & 339 & 2826 & 1180 & 483 \\
\hline Min & - & 1634 & 972 & 470 & 1834 & 783 & 333 & 1960 & 7800 & 315 & 2610 & 1157 & 462 \\
\hline Mean & - & 1723 & 1049 & 526 & 1913 & 854 & 384 & 2063 & 837 & 355 & 2815 & 1197 & 490 \\
\hline Max & - & 1829 & 1096 & 560 & 2012 & 891 & 416 & 2203 & 876 & 381 & 3023 & 1220 & 518 \\
\hline SD & - & 74.8 & 42 & 32.4 & 63 & 30.8 & 24.6 & 80.6 & 27 & 19 & 131.5 & 18 & 17 \\
\hline \multicolumn{14}{|c|}{ Bukowska Forest } \\
\hline beech1 & 67 years $-100 \%$ & 3668 & 1601 & 702 & 3789 & 1534 & 586 & 3619 & 1633 & 613 & 3066 & 2572 & 1126 \\
\hline beech2 & 67 years $-100 \%$ & 1782 & 1578 & 675 & 3646 & 1508 & 586 & 3470 & 1582 & 606 & 2928 & 2408 & 1062 \\
\hline beech3 & 62 years $-100 \%$ & 1708 & 1619 & 709 & 4104 & 1619 & 619 & 3833 & 1690 & 639 & 3160 & 2485 & 1079 \\
\hline beech4 & $\begin{array}{c}40 \text { years }-60 \% \\
30 \text { years }-30 \% \\
60 \text { years }-10 \%\end{array}$ & 1796 & 1679 & 747 & 3968 & 1608 & 624 & 3671 & 1660 & 627 & 2971 & 2489 & 1104 \\
\hline beech5 & 150 years $-100 \%$ & 3344 & 1545 & 695 & 3587 & 1531 & 597 & 3386 & 1620 & 625 & 2741 & 2544 & 1169 \\
\hline beech6 & 152 years $-100 \%$ & 3408 & 1558 & 682 & 3447 & 1519 & 597 & 3218 & 1569 & 610 & 1489 & 2436 & 1140 \\
\hline beech7 & 112 years $-100 \%$ & 3258 & 1480 & 667 & 3500 & 1526 & 603 & 3194 & 1555 & 613 & 2230 & 2146 & 1018 \\
\hline beech8 & 132 years $-100 \%$ & 3548 & 1509 & 651 & 3563 & 1536 & 597 & 3253 & 1587 & 605 & 2338 & 2159 & 999 \\
\hline beech9 & $\begin{array}{l}40 \text { years }-80 \% \\
55 \text { years }-20 \%\end{array}$ & 4180 & 1718 & 737 & 4221 & 1667 & 644 & 3901 & 1712 & 654 & 3473 & 2762 & 1198 \\
\hline Min & - & 3258 & 1480 & 651 & 3447 & 1508 & 586 & 3194 & 1555 & 605 & 2230 & 2146 & 999 \\
\hline Mean & - & 3633 & 1588 & 696 & 3758 & 1561 & 606 & 3505 & 1623 & 621 & 2822 & 2445 & 1099 \\
\hline Max & - & 4180 & 1718 & 747 & 4221 & 1667 & 644 & 3901 & 1712 & 654 & 3473 & 2762 & 1198 \\
\hline SD & - & 282.1 & 76.6 & 31.6 & 278.9 & 55.9 & 19.4 & 265.2 & 55.2 & 16.6 & 408.3 & 194.4 & 66.4 \\
\hline
\end{tabular}


to the growth of new needles. Although pine needles remain on a tree for a period of about three years (Przybylski 1970), some new needles grow every spring. This affects the reflectance in the green channel (channel two) because new needles have less chlorophyll than old ones. (Wężyk et al. 2003).

On 30.10.2010, a spike in visible spectrum radiation was recorded in the red channel (channel three) for beech trees. Spectral reflectance for beech was at that time 386 SFRI units higher, or almost twice the level recorded for pine. This relation in reflectance between the analyzed stands is explained by changes occurring inside beech leaves. As leaves grow old, the chlorophyll content in them decreases (Domański 2002), leading the reflectance in both the green and red channels (channels 2 and 3, respectively) to rise. In the process of aging, chlorophyll in leaves degrades more quickly than other organic pigments, such as carotenoids, which reflect light in the green and red spectra (Sanger 1971 after Kumar et al. 2002). This causes beech leaves to acquire a yellow and orange colouring. A decrease in chlorophyll content is also visible in the reflectance indices in the green channel for pine stands, which might be due to the aging of some needles. It was also noted that the maximum reflectance index in this spectrum corresponded with research by Linder (1972), in which the lowest chlorophyll content was recorded in October.

\section{Infrared spectrum}

Analysis of the reflectance indices for the nearand mid-wavelength infrared spectra (Table 2) reveals significant differences between the indices for pine and beech stands. In the case of near infrared (channel 4), these differences are most visible on the first three dates in the vegetation season. On those dates, the indices were 1,732 SRFI units higher in beech stands. This is because beech leaves and pine needles have different internal structures. Beech leaves are composed of a tissue called spongy mesophyll, which contains a large amount of air-filled space (Kumar et al. 2002). The tissue is a poor conductor of infrared light, which directly translates into higher reflectance indices in this spectrum (Ciołkosz et al. 1999). On the other hand, the tissue of pine nee- dles contains less air (Kumar et al. 2002), which results in lower reflectance indices in the infrared spectrum.

In the autumn date $(30.10 .2010)$, the situation was quite different. The reflectance values for near infrared (channel 4) in the beech stand were decidedly lower than on earlier dates in the vegetation period. This was caused by the aging of leaves, which during this process losing both dry matter and macroelements such as nitrogen, phosphorus and potassium (Domański 2002). These losses change the leaves' internal structure, and as a consequence, decreased the reflectance indices for near infrared (Kumar et al. 2002). The drop was so serious (over 680 SFRI units) that reflectance indices in channel 4 for both pine and beech became similar to each other - the average for the indices in this spectrum were 2,822 units SRFI for beech and 2,815 for pine.

Throughout the entire vegetation season, major differences between the two tree species occurred in the reflectance in the short-wavelength infrared channels (channels 5 and 7). Both channels showed higher values for the beech stand. These differences were related to water saturation of the leaves and needles (Weng 2011). The higher the saturation, the lower value of the reflectance index for long-wave radiation (Kumar et al. 2002). The lower level of saturation in beech leaves may have resulted from intensive vaporization. Research by Hueber (1953 after Kieliszewska-Rokicka 1993) confirms that transpiration in beech leaves is almost three times more intensive than in pine needles. The greatest differences in reflectance values between the analyzed stands occurred in autumn and equalled on average 1,248 units SRFI for channel 5, and 609 units for channel 7. This was caused by the aging of beech leaves and a decrease in their water saturation due to withering (Ciołkosz et al. 1999), which resulted in higher reflectance for the beech stands.

\section{Vegetation indices}

\section{NDVI}

The Normalized Difference Vegetation Index (NDVI) (Rouse et al. 1973) is the most popular vegetation index because it can reveal information about changes in biomass quantity, chloro- 
phyll content, and drought stress in plants (Liang 2004). The index has the highest values when reflectance is maximal in infrared and minimal in channel red. The near infrared spectrum is sensitive to changes in leaves' structure; the higher the reflectance in this channel, the greater the volume of leaves. The red channel, in turn, is sensitive to chlorophyll content; thus, the lower reflectance in the channel, the greater the content. The two spectra combined may be used to estimate both biomass quantity and chlorophyll content.

Analysis of the graph in Fig. 3 reveals seasonal variation in NDVI for both pine and beech stands. During the vegetation season, variation was greater for beech forests. The average NDVI recorded for this species equalled about 0.337. For pine, the average was almost three times smaller, that is: 0.103 . On the other dates during the vegetation season, differences between the two species were also visible. The first three dates were characterized by higher indices in beech stands, which was influenced mainly by higher reflectance values from the near infrared channel. In April, the average difference between pine and beech amounted to 0.094, whereas in July it was 0.122. In September, the average difference was smallest and equalled merely 0.054 . During this period, reflectance values for chan- nel 4 in beech dropped, while they rose for pine. In addition, in comparison with earlier dates, reflectance in channel 4 was higher for pine and lower for beech. The greatest difference in NDVI was recorded in October. At that time, beech stands had decisively lower values than in September. At the same time, NDVI for pine also decreased, but by a smaller amount than for beech. Overall, NDVI in that period was higher for pine stands. At the same time, the variation in the indices recorded for pine stands was greater than for beech.

\section{TVI}

The transformed Vegeatation Index (TVI) (Rouse et al. 1973) is a modification of NDVI. Analysis of the graph illustrating TVI (Fig. 4) reveals its similarity to Fig. 3, both in regard to the shape of the curves and to the relation between curves generated for pine and beech. According to the graph, indices were higher for beech stands in April, July and September. In April, the average difference between TVI was 0.053; in July it rose to 0.066 , whereas in September it was the smallest and equalled 0.032 . It is worth noting that in that period the difference between the lowest recorded index for beech and the highest recorded index for pine was merely 0.009. As in

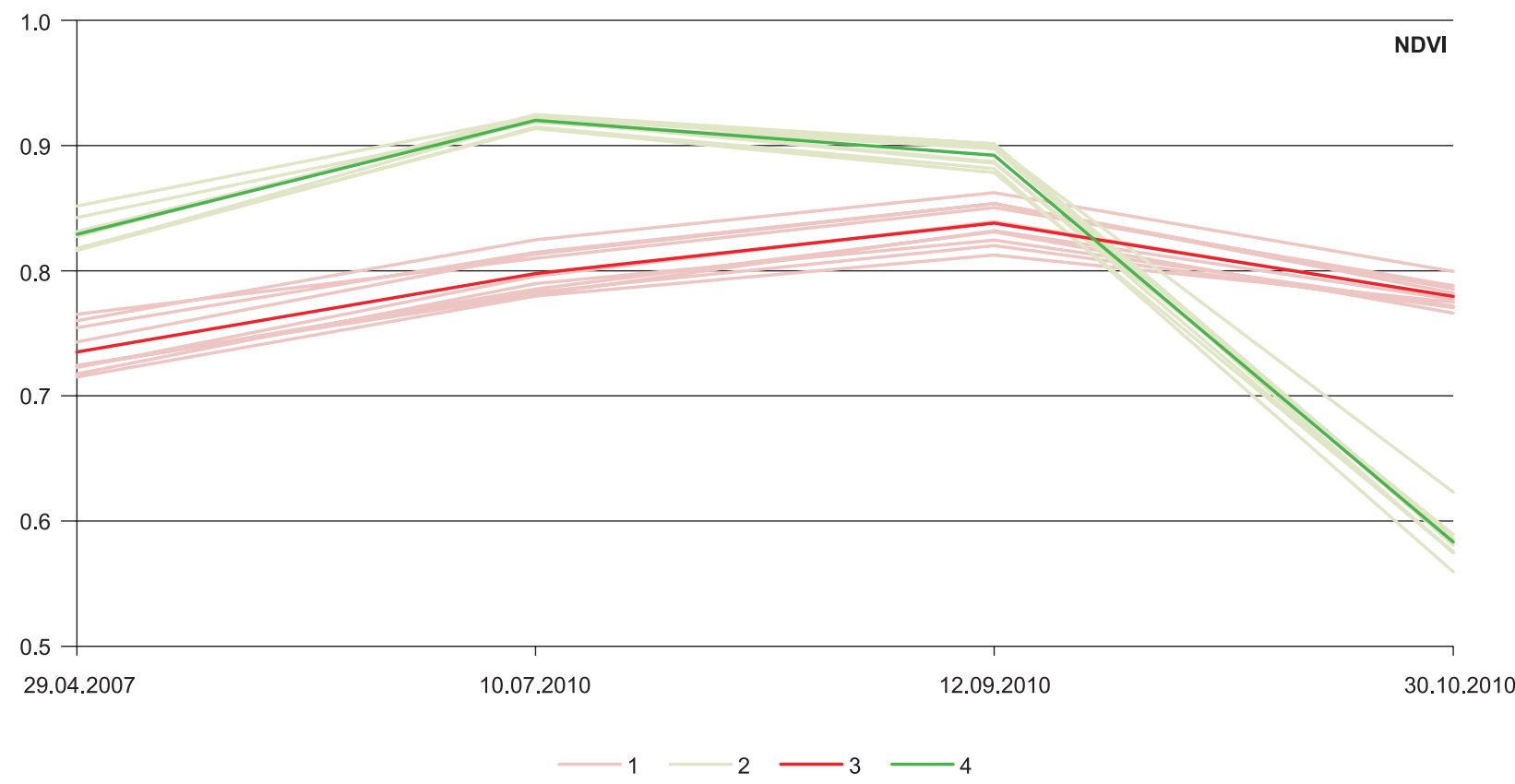

Fig. 3. Variation in the NDVI indices of pine and beech stands on each date in the vegetation season 1 - variation in indices for test areas of pine; 2 - variation in indices for test areas of beech; 3 - average index for pine stand; 4 - average index for beech stand 
the case of NDVI, the biggest difference in TVI between beech and pine was recorded in Autumn, when it amounted to 0.120. In October, pine stands had higher measurements.

\section{Green NDVI}

As in the case of NDVI, Green Normalized Vegetation Index, or Green NDVI (Gitelson et al. 1996) uses in its calculations indices recorded in the near infrared spectrum. Unlike NDVI, however, this index uses different element; i.e. reflectance value recorded in the green spectrum of radiation. This is because the index is based on an inversely proportional relationship between the green spectrum of radiation and chlorophyll content (Daughtry et al. 2000), and it was precisely for measuring chlorophyll content that the index was created in the first place (Gitelson et al. 1996). Taking into account both the chlorophyll content in leaves and their structure (near infrared channel), Green NDVI may be a useful tool for estimating biomass quantity and chlorophyll content, similar to NDVI.

Analysis of Green NDVI recorded for both tree species (Fig. 5) revealed variation throughout the vegetation season. For beech stands, maximal values occurred in July. For pine this occurred in September. Both months were characterized by large differences in the indices for both species, which were much higher for beech. The greatest difference in average NDVI was recorded in July and equalled 0.118. In September, it was 0.071. The situation was decisively different in April and October, when Green NDVI for both species were similar. In April, the average for beeches was higher by 0.018 , and in October it was lower by 0.006 . This cannot serve, however, as a basis for differentiating between the analyzed stands because their recorded indices overlapped.

\section{NDGI}

Normalized Difference Greenness Index (NDGI) (Chamard et al. 1991 after Bannari et al. 1995) is based on reflectance values in the visible spectrum of radiation. This index can provide information about differences in the content of various pigments and their variation throughout the entire vegetation season. As was the case with previous indices, NDGI (Fig. 6) during the vegetation season had greater variation in beeches than in pines. This variation was significantly affected by autumn, when indices for beeches dropped below zero. This was because, for beech stands, radiation in the channel red increased in comparison with the channel green. The biggest difference in the average NDGI between beeches and pines was

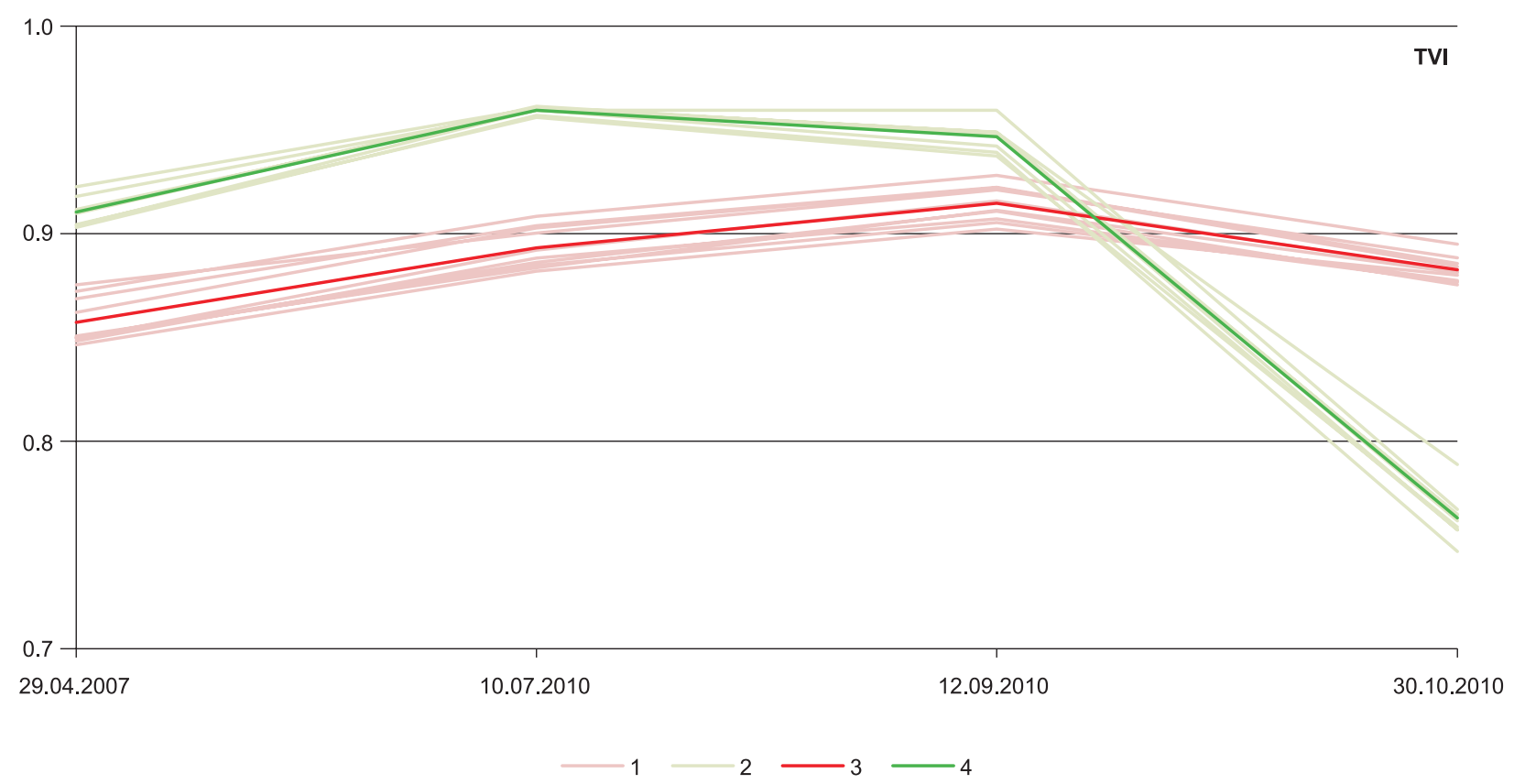

Fig. 4. Variation in the TVI indices of pine and beech stands on each date in the vegetation season

1 - variation in indices for test areas of pine; 2 - variation in indices for test areas of beech; 3 - average index for pine stand; 4 - average index for beech stand 


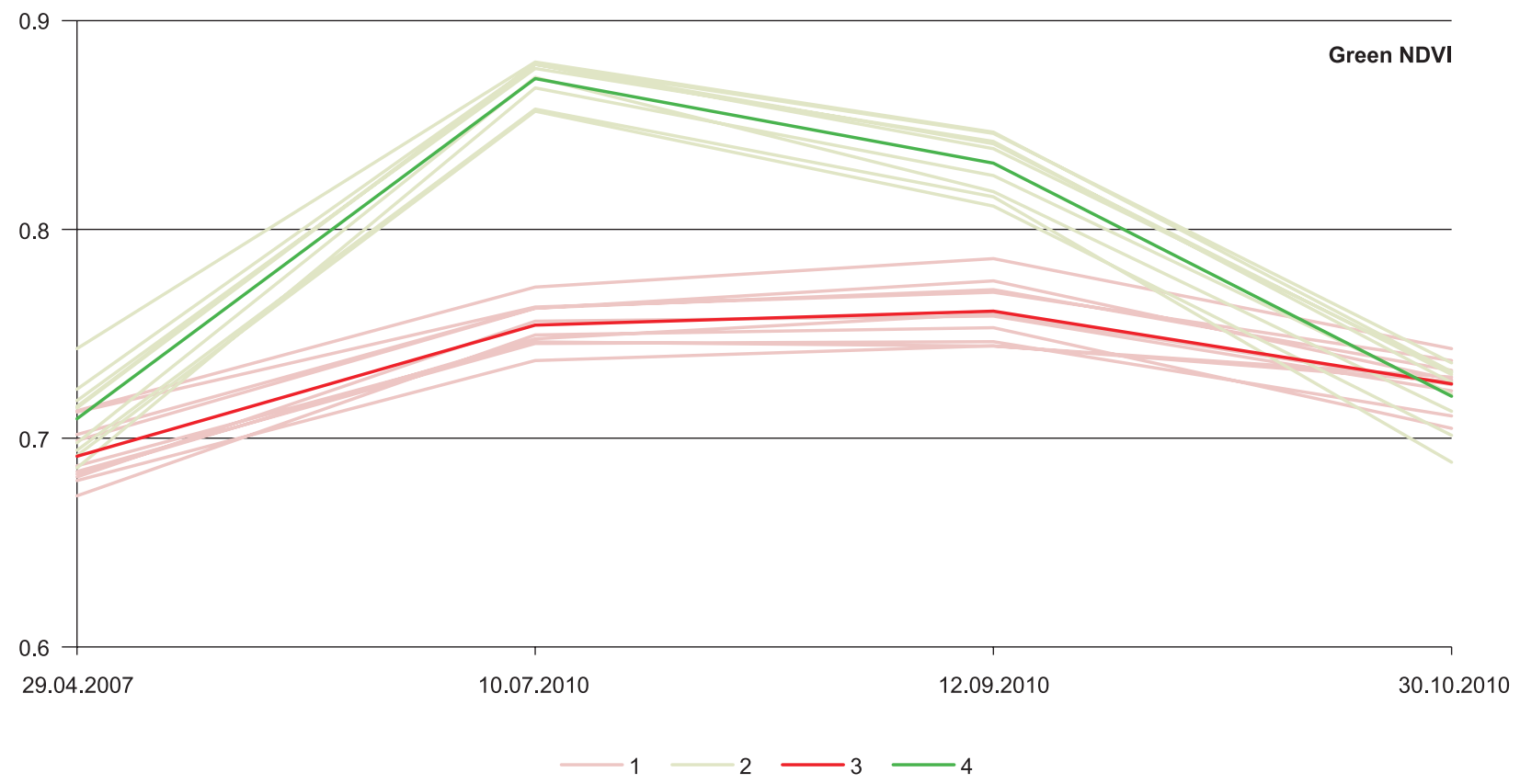

Fig. 5. Variation in the Green NDVI indices of pine and beech stands on each date in the vegetation season 1 - variation in indices for test areas of pine; 2 - variation in indices for test areas of beech; 3 - average index for pine stand; 4 - average index for beech stand

also recorded in autumn, and equalled 0.359. Differences recorded in September were decisively smaller, but due to an overlap between NDGI for both beech and pine, differentiating between them is not possible. The remaining two months were different in character than September and October: in April and July beech stands had higher indices. In April, the average difference was 0.202, while in
July it was 0.131 . April was also characterized by a greater difference due to higher reflectance in the green channel in beech stands.

\section{NDI}

Unlike the previous index, Normalized Difference Index (NDI) (McNairn, Protz 1993 after Bannari et al. 1995) is based on reflectance values

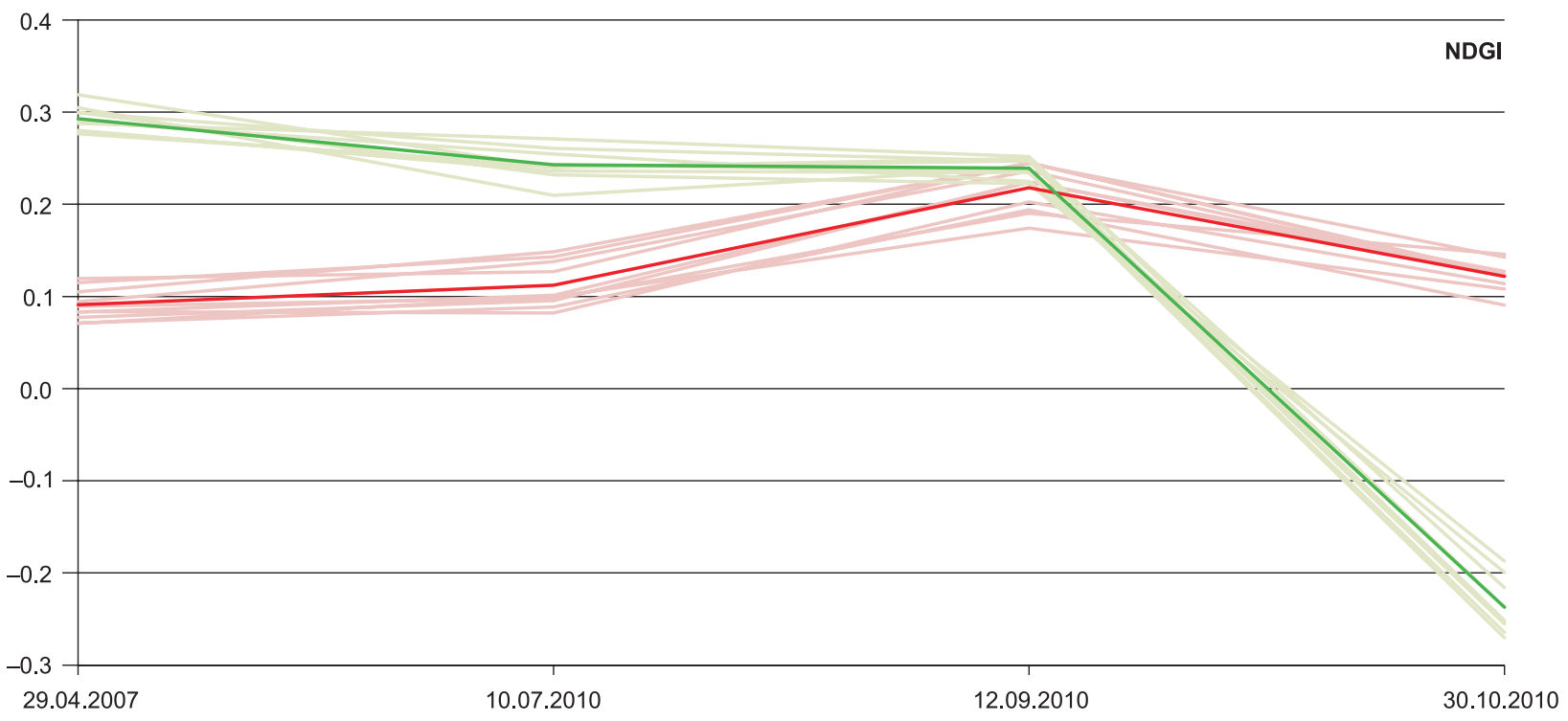

Fig. 6. Variation in the NDGI indices of pine and beech stands on each date in the vegetation season

1 - variation in indices for test areas of pine; 2 - variation in indices for test areas of beech; 3 - average index for pine stand; 4 - average index for beech stand 
recorded out of the visible spectrum of radiation. The short-wavelength radiation spectrum is sensitive to water saturation in leaves. In combination with measurements of leaves' volume (by means of near infrared), the index can provide information about variations in water saturation in leaves throughout the vegetation season, which is why the index was initially used in agricultural remote sensing (Piekarczyk 2009). The formula for calculating the index is as follows:

$$
N D I=\frac{R_{N I R}-R_{M I R}}{R_{N I R}+R_{M I R}} .
$$

Analysis of the NDI graph (Fig. 7) reveals that the greatest differences in indices between beech and pine stands were visible in spring and autumn. In April, the average difference between pine and beech stands equalled 0.146. In October, it was almost twice as high and amounted to 0.338 . It is also worth noting that in both periods the relationship between the NDI of pine and beech were different - in April they were higher for beech; in October for pine. In autumn, there was also a relationship between NDI and the age of stands, which was visible for both pine and beech. Younger stands had higher indices, which might indicate that in autumn young trees maintain a higher water saturation level than older ones. That kind of relation was also observed on pine stands in Notecka Forest (Piekarski, Dzieszko 2013). During summer, recorded differences in indices were not that significant; in July they overlapped, while in September the highest NDI recorded for a pine stand was equal with the lowest index recorded for a beech stand. In the case of the latter, the trees were between 40 and 55 years old, which made it one of the youngest analyzed test areas. In the case of pine, the lowest recorded index was recorded in the area where trees were 74 years old, which made them one of the oldest in the research area.

\section{Conclusions}

The major purpose of this work was to determine quantitative differences in vegetation indices between pine stands in Goleniowska Forest and beech stands in Bukowska Forest. The indices were based on spectral characteristics, and the differences measured on four distinct dates in the vegetation season. Significant differences were discovered between the indices calculated for areas of pine stands and those calculated for beech stands. The reasons for these differences lie in the trees' structure, biochemical attributes and variation throughout the vegetation season. In spring

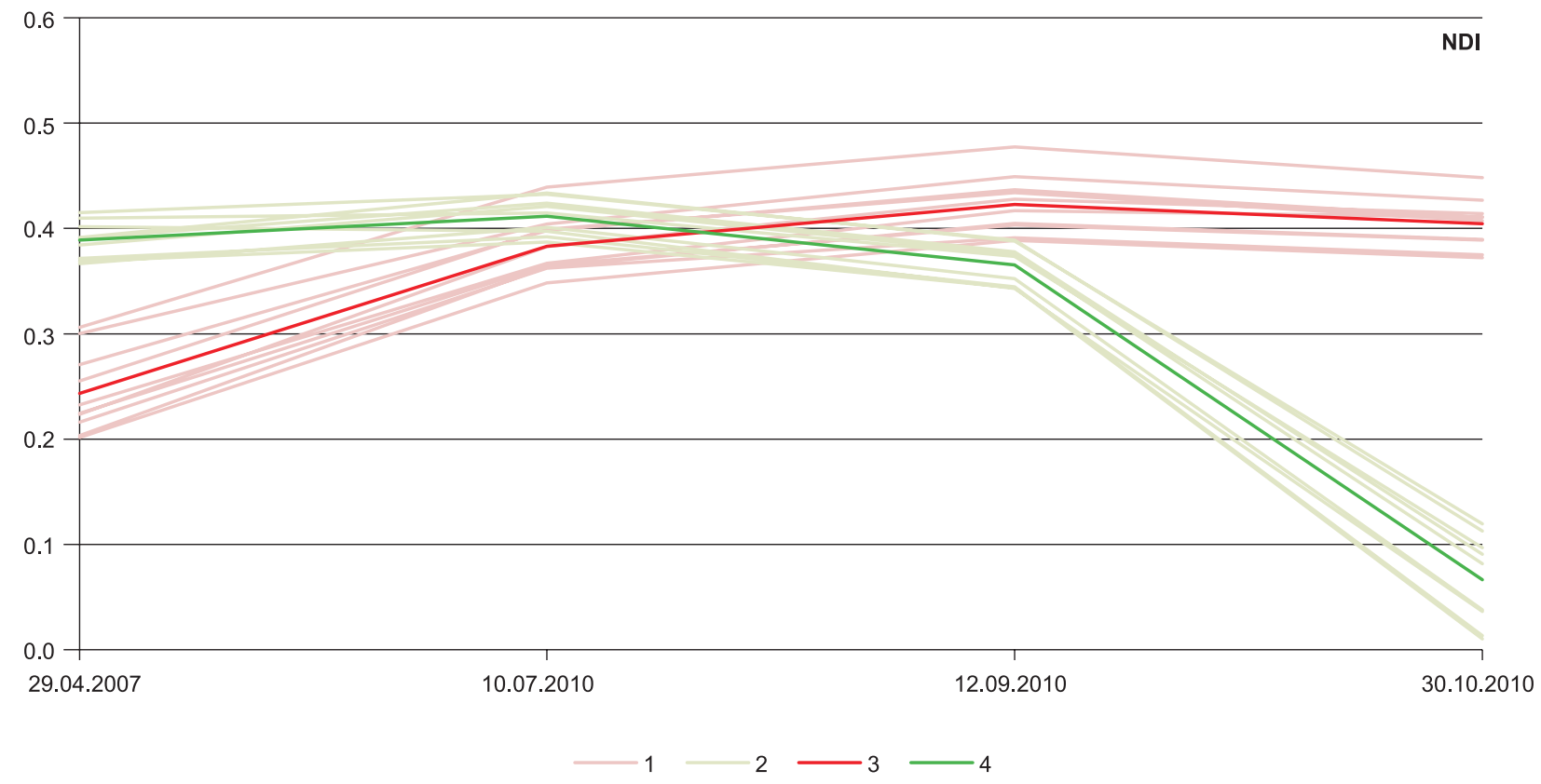

Fig. 7. Variation in the NDI indices of pine and beech stands on each date in the vegetation season

1 - variation in indices for test areas of pine; 2 - variation in indices for test areas of beech; 3 - average index for pine stand; 4 - average index for beech stand 
(April), the index that best represented differences between the analyzed stands was NDGI; the difference between the analyzed stands at that time equalled 0.157 SRFI. In early summer (July), the index that most clearly indicated differences between pine and beech was NDVI. At that time, the difference between the indices for beech and pine amounted to 0.089 SRFI units. During late summer (September), the best indicator of differences was Green NDVI, according to which the difference was 0.025 SRFI units. In autumn (October), the index that best showed the differences was again NDGI - in this case, the difference between average for the index for beech and the average index for pine was 0.278 SRFI units. The only indices that allowed for differentiation between the analyzed stands throughout the entire research period were NDVI and its modification, TVI. The remaining indices differentiated between beech and pine only on some of the four dates when the analysis took place.

Performed interpretations allowed to improve remote differentiating stands of pine and beech in different ages. It is worth noting that on the first three dates studied, the widest range of difference in the indices was between young beech stands and the oldest pine stands. In October, the situation was the reverse: the greatest range of difference was between young pine stands and old beech stands.

\section{Acknowledgements}

This research was funded by Adam Mickiewicz University in Poznań. The U.S. Landsat project management is thanked for provision of the Landsat 5 TM data. The authors would like to thank the forest inspectorates in Kliniska and Gryfino for sharing their forest survey data.

\section{References}

Bannari A., Morin D., Bonn F., 1995. A Review of Vegetation Indices. Remote Sensing Reviews 13: 95-120.

Białobok S., 1990. Buk zwyczajny. Fagus Sylvatica L. Państwowe Wydawnictwo Naukowe, Warszawa-Poznań.

Borówka R., Friedrich S., Hesse T., Jasnowska J., Kochanowska R., Opęchowski M., Stanecka E., Zyska W., 2004. Przyroda Pomorza Zachodniego. Oficyna In Plus, Szczecin.

Castro K.L., Sanchez-Azofeifa A.G., 2008. Changes in Spectral Properties, Chlorophyll Content and Internal Me- sophyll Structure of Senescing Populus balsamifera and Populus tremuloides Leaves. Sensors 8: 51-69.

Ciołkosz A., Miszalski J., Olędzki J.R., 1999. Interpretacja zdjęć lotniczych. Wydawnictwo Naukowe PWN, Warszawa.

Colombo R., Meroni M., Marchesi A., Busetto L., Rossini M., Giardino C., Panigada C., 2008. Estimation of leaf and canopy water content in poplar plantations by means of hyperspectral indices and inverse modeling. Remote Sensing of Environment 112: 1820-1834.

Daughtry C.S.T., Walthall C.L., Kim M.S., Brown de Colstoun E., McMurtrey J.E., 2000. Estimating Corn Leaf Chlorophyll Concentration from Leaf and Canopy Reflectance. Remote Sensing of Environment 74: 229-239.

de Kok R., Kozioł K., Wężyk P., 2005, Zastosowanie klasyfikacji obiektowej wysokorozdzielczych obrazów teledetekcyjnych oraz analiz przestrzennych GIS w kartowaniu drzewostanów. Roczniki Geomatyki 3(4): 99-108.

Domański R., 2002. Fizjologia roślin z elementami biochemii. Wydawnictwo Akademii Rolniczej im. Augusta Cieszkowskiego w Poznaniu, Poznań.

Gitelson A.A., Kaufman Y.J., Merzylak M.N., 1996. Use of a Green Channel in Remote Sensing of Global Vegetation from EOS-MODIS. Remote Sensing of Environment 58: 289-298.

Gitelson A.A., Gritz Y., Merzylak M.N., 2003. Relationships between leaf chlorophyll content and spectral reflectance and algorithms for non-destructive chlorophyll assessment in higher plant leaves. Journal of Plant Physiology 160: 271-282.

Haapanen R., Ek A.R., Bauer M.E., Finley A.O., 2004. Delineation of forest/nonforest land use classes using nearest neighbor methods. Remote Sensing of Environment 89: 265-271.

Kieliszewska-Rokicka B., 1993. Transport. In: Białobok S., Boratyński A., Bugała W., Biologia sosny zwyczajnej. Sorus, Poznań-Kórnik: 125-137.

Kim M., Madden M., Warner T.A., 2009. Forest Type Mapping using Object-specific Texture Measures from Multispectral Ikonos Imagery: Segmentation Quality and Image Classification Issues. Photogrammetric Engineering E Remote Sensing 75: 819-829.

Kumar L., Schmidt K., Dury S., Skidmore A., 2002. Imaging Spectrometry and Vegetation Science. In: van der Meer F.D., de Jong S.M., Imaging Spectrometry. Basic Principles and Prospective Applications, Springer, Dordrecht.

Liang S., 2004. Quantitative Remote Sensing of Land Surfaces. Wiley-Interscience, New Jersey.

Linder S., 1972, Seasonal Variation of Pigments in Needles A Study of Scots Pine and Norway Spruce. Seedlings Grown under Different Nursery Conditions. Studia Forestalia Suecica 100: 5-37.

Mallinis G., Koutsias N., Tsakiri-Strati M., Karteris M., 2008. Object-based classification using Quickbird imagery for delineating forest vegetation polygons in a Mediterranean test site. ISPRS Journal of Photogrammetry \& Remote Sensing 63: 237-250.

Mirek Z., Nikiel A., Paul W., Wilk Ł., 2005. Ostoje roślinne w Polsce. Instytut Botaniki im. W. Szafera Polskiej Akademii Nauk, Kraków.

O’Neill A.L., Kupiec J.A., Curran P.J., 2002. Biochemical and reflectance variation throughout a Sitka spruce canopy. Remote Sensing of Environment 80: 134-142.

Oleksyn J., 1990. Wymiana gazowa i gospodarka wodna. In: Białobok S., Buk zwyczajny . Fagus Sylvatica L., Państwowe Wydawnictwo Naukowe, Warszawa - Poznań: 97-122. 
Paris J., 2005. FAQs by Jack B, Tutorials about Remote Sensing Science and Geospatial Information Technologies. Online 18.05.2012 - http://www.microimages.com/sml/smlscripts/ParisScripts/FAQsbyJackB.pdf

Piekarczyk J., 2009. Remote sensing in agriculture. In: Zwoliński Z. (ed.), GIS - platforma integracyjna geografii. Bogucki Wydawnictwo Naukowe. Poznań, 55-66.

Piekarski P., Dzieszko P., 2013. Wpływ wieku drzewostanów na ich charakterystyki spektralne i wartości wybranych wskaźników wegetacyjnych. Roczniki Geomatyki 11: 6779.

Piekarski P., Zwoliński Z., 2012. Dywersyfikacja odbicia spektralnego i wskaźników wegetacji dla drzewostanów sosnowych i bukowych, Nizina Szczecińska. In: Zwoliński Z. (ed.) GIS - teledetekcja środowiska. Bogucki Wydawnictwo Naukowe. Poznań: 31-60.

Przybylski T., 1970. Morfologia. In: Białobok S., Sosna zwyczajna Pinus silvestris L. Państwowe Wydawnictwo Naukowe, Warszawa - Poznań: 86-123.

Rąkowski G., Wójcik J., Walczak M., Smogorzewska M., Brodowska M., 2005. Województwo zachodniopomorskie. In: Rąkowski G., Rezerwaty przyrody w Polsce Pótnocnej, Instytut Ochrony Środowiska, Warszawa: 11-96.

Rouse Jr. J.W., Haas R.H., Schell J.A., Deering D.W., 1973. Monitoring the vernal advancement and retrogradation (Green wave effect) of natural vegetation. Progress Report RSC: $1-112$.

Sims D.A., Gamon J.A., 2002. Relationships between leaf pigment content and spectral reflectance acrossa wide range of species, leaf structures and developmental stages. Remote Sensing of Environment 81: 337-354.
Smith M.-L., Ollinger S.V., Martin M.E., Aber J.D., Hallett A., Goodale C.L., 2002. Direct estimation of aboveground forest productivity through hyperspectral remote sensing of canopy nitrogen. Ecological Applications 12(5): 1286-1302.

Virk R., King D., 2006. Comparison of Techniques for Forest Change Mapping UsingLandsat Data in Karnataka, India. Geocarto International 21(4): 49-57.

Weng Q., 2011. Advances In Environmental Remote Sensing, Sensors, Algorithms, and Applications. CRC Press, Taylor\&Francis Group.

Wężyk P., Wertz B., Waloszek A., 2003. Skaner hiperspektralny AISA (Airborne Imaging Spectrometer for Applications jako narzędzie pozyskiwania informacji o ekosystemie leśnym. Materiały Ogólnopolskiego Sympozjum Geoinformacji. Geoinformacja zintegrowanym narzędziem badań przestrzennych, Wrocław-Polanica Zdrój 13B: 485496.

Zajączkowski G., Wężyk P., 2004. Techniki teledetekcyjne w inwentaryzacji urządzeniowej lasu. Roczniki Geomatyki 2(4): 41-50.

Zheng D., Rademacher J., Chen J., Crow T., Bresee M., Le Moine J., Ryua S.-R., 2004. Estimating aboveground biomass using Landsat 7 ETM+ data across amanaged landscape in northern Wisconsin, USA. Remote Sensing of Environment 93: 402-411.

Zwoliński Z., (ed.), 2012. GIS - remote sensing of environment. Bogucki Wydawnictwo Naukowe, Poznań. 